\title{
Denotative and Connotative Meaning of Signs in Lombok Musical Instrument (Gendang Beleq)
}

\author{
Fahimah Saifuddin
}

English Linguistics, Faculty of Cultural Sciences, Universitas Padjajaran Bandung, Indonesia

\begin{abstract}
The aims of this study is to describe and analyze connotative meaning of of signs in Lombok Musical Instrument (Gendang beleq). The researcher divides the data into two parts which are primery and secondary data. The primery data consists of magazines, books guide, and the data from internet and the result of interview. the method used in this study is qualitative. The main theory that the researcher used is Roland Barthes Theory. The result of this study shows that the connotative meaning of signs in Lombok Musical Instrument (Gendang Beleq) was Courageous, spirit, strength.
\end{abstract}

Keywords- Semiotic, denotative and connotative meaning, Lombok Musical Instrument (Gendang Beleq).

\section{INTRODUCTION}

Lombok is one of the islands located in eastern of Indonesia. This island is also still rich in arts and cultures which are still preserved by local communities. The majority of Lombok island is indigenous Sasak tribe but the other tribes are Tionghoa, Bali, and Arab tribes also stay in Mataram city. Islam becomes the majority of Lombok society. In addition, other religions in Lombok are Christian, Catholic, Hindu, Buddha, and Kong $\mathrm{Hu} \mathrm{Cu}$ (wangsa, 2016).

Because Lombok is inhabited by various ethnic and religion, of course, it becomes a consideration of researcher in determining research data. Some magazines that become the source of data in this research such as Enjoy Mataram magazine published by Tourism and Culture Office of Mataram city.

In general, the meaning of the words is distinguished by a denotative and connotative meaning. Denotative meaning is meaning that does not contain other meanings or values, whereas connotative meaning is the additional meaning or sense value contained in a word. For example the word 'rose flower'. Denotative meaning of rose flower is plant in flower categories that has thorns in stems and petals and usually red, white, and pink colors. Denotative and connotative meaning are created not only by the words but also by the images. To create an image connotation in semiotics, denotative and connotative messages must be distinguished first because the second-level semiotics connotation system is built on a denotative system. In pictures or photographs, the denotation meaning is the meaning that is delivered as a whole and the connotation meaning is the meaning generated by the image elements in photo.

Semiology therefore aims to take in any system of sign, whatever their substance and limits of image, gesture, musical sounds, objects, and the complex associations of all these, which form the content of ritual, convention or public entertainment: these constitute at least systems of signification (Barthes, 1964).

Chandler (2007) stated that denotation and connotation are terms describing the relationship between the signifier and its signified, and an analytic distinction is made between two types of signified: a denotative signified and a connotative signified. Denotation tends to be described as the definitional, literal, obvious or common-sense meaning of a sign. Means that denotative meaning is what the dictionary attempts to provide.

Barhes (Shobur, 2009) stated "there are some levels of the relation between signifier and signified called "staggered systems"'. The two of levels are Denotation and Connotation. Denotation is a level of sign explaining the correlation between signifier and signified in which the sign produce the explicit, direct, and real meaning. Whereas, Connotation is a level of sign explaining the correlation between signifier and signified in which it is explained an implicit, indirect, unreal meaning.

Denotative meaning is the first order meaning which is objective that can be given to symbols. It is by linking directly between the symbols with a reality or the designated phenomenon. Then the meaning of connotation is the second order meaning that can be given to symbols with reference to cultural values that are therefore on the second level.

Sign can be examined through two orders of signification. In the first order, the sign can be identify its background which is signifier (2) and signifier (2) order. This order is the denotative order by interpreting the signs literally. After finding the literal meaning, then go to the second order of signification that is connotative meaning. In this second order of signification, the cultural context is needed. 
II. AIM OF THE STUDY

The aims of this study is to analyze and describe the connotative meaning of sign in Lombok Traditional Music (Gendang Beleq). For this purpose, the magazine will be analyzed by using Brthes theory of semiotics that is two order of signification to know the connotative meaning of Lombok Musical Instrument (Gendang Beleq).

\section{THE METHOD}

The researcher divides the data into two parts which are primery and secondary data. The primery data consists of magazines, books guide, and the data from internet and the result of interview.. In this case, the researcher as an interviewer does the interview to get more information about some attractions in Lombok and its history.

The technique of the primery data collecting can be described through some steps such as collecting some magazines that consist of verbal and nonverbal and selecting the data which consist of verbal and nonverbal. However, the secondary data is a kind of interview. The researcher interviews some cultural observers to make the result of research more credible.

\section{FINDINGS AND DISCUSSION}

First order of signification

\begin{tabular}{|l|l|}
\hline $\begin{array}{l}\text { 1. Signifier } \\
\text { Two men, Gendang Beleq }\end{array}$ & $\begin{array}{l}\text { 2. Signified } \\
\text { Two people who are holding Gendang Beleq, they face each other by } \\
\text { using Sasak traditional clothes such as Cepuk on his head, traditional } \\
\text { clothes called Godek Nongkek and Sarong in the form of a typical } \\
\text { Sasak tribe Songket. }\end{array}$ \\
\hline $\begin{array}{l}\text { SIGN } \\
\text { Signifier }\end{array}$ & \\
&
\end{tabular}

In the first order of signification, the sign can be seen as signifier and signified. Signifier (1) is two men carrying a big drum. Then the two men, signifier, are carrying big drum. Lombok people called it as Gendang Beleq. The two men faced each other. They used the traditional clothing of the sasak tribe, Two people who are holding Gendang Beleq, they face each other by using Sasak traditional clothes such as Cepuk on his head, traditional clothes called Godek Nongkek and Sarong in the form of a typical Sasak tribe Songket. This stage is the denotation meaning.

Second order of signification

\begin{tabular}{|l|l|}
\hline SIGN & Signified \\
Signifier & Spirit, strength, \\
& Geating \\
SIGN \\
With a loud voice, Gendang Beleq is played by the sasak youth to give the spirit and strength to \\
the war fighters who have finished their war.
\end{tabular}


In this second order of signification, cultural context has played a role. The first order of signification (I) is used to analyze second order of signification. In this second order of signification, the signifier interpreted as connotation by the meaning as "two people who are holding Gendang Beleq, they are facing each other by using traditional clothes Sasak that is using Cepuk on his head and traditional clothes called Godek Nongkek and use a sarong in the form of songket typical Sasak. Before analyze the connotative meaning of this picture, let tray to chack the history of Gendang beleq first.

Gendang Beleq is a traditional musical art played in a group by using several kinds of musical instruments and the big drum as the main musical instrument. Drum musical instrument used slightly different from the drum musical instrument in general because the drums have a larger size. Gendang Beleq is a traditional art that comes from the Sasak tribe on the Lombok island, West Nusa Tenggara Province.

Most people consider that this music was from Bali because the rhythm, rhythm, and flute sound almost similar to Balinese music. Looking at the history, in the 17 th century Lombok was dominated by the Bali kingdom that was the kingdom of Klungkung. Then, in the 18th century was dominated by the kingdom of Karangasem. Precisely, in the seventeenth century, Lombok was struggled by two kingdoms. Those were the kingdom of karangasem Bali and kingdom of Makasar from Sumbawa. At the beginning of the 17th century Karangasem people crossed to the island of Lombok and established some villages and build political control in Lombok that is precisely west Lombok.

Long time ago, the Gendang Beleq is just a musical instrument that accompanies the soldiers when it would fight into the battlefield. The signified of this image are the sound of this drum was believed to make the soldiers became more courageous, spirit, and strength to sacrifice in defending the kingdom. But over the time, Gendang Beleq was used as entertainment that was displayed at cultural events, arts, or traditional wedding celebrations.

The myth of Gendang beleq for Sasak society was that the sound of Gendang Beleq can make the soldiers more courageous in war. However, Gendang Beleq, nowadays, are used in some cultural event especially in traditional wedding celebration. The Sasak Society belief that the sound of the drum can make the wedding celebrations more lively.

\section{ACKNOWLEDGEMENTS}

Special thanks to Lembaga Pengelola Dana Pendidikan (LPDP) RI as one of the funding agencies and credible scholarship in Indonesia that supported this research.
REFERENCES

[1] Barthes, R. (1964). Element of Semiology. paris: Hill and Wang.

[2] Chandler, D. (2007), the Basics Semiotics, Second Edition. London and New York: Routledge Taylor and Francis Group.

[3] Sobur, A. (2009). Semiotika Komunikasi. Bandung: PT Remaja Rosdakarya.

[4] Wangsa, L. S. (2016). Pelangi Budaya dan Sejarah Kota Mataram. Mataram: Sanabil.

MAGAZINE

[5] The Culture and Tourism Office of Mataram City (2013), Enjoy Mataram. Mataram: The Culture and Tourism Office of Mataram City. 